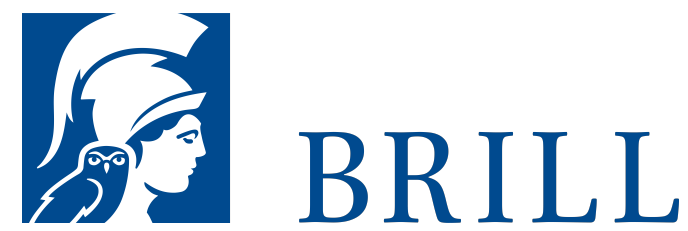

\title{
Pflicht zum Untergang
}

Die deutsche Kriegsführung im Westen des Reiches 1944/45

Author: John Zimmermann

Ab September 1944 wurde der Zweite Weltkrieg auch auf dem Boden des Reichsgebietes ausgetragen, er rückte im Osten wie im Westen mit jedem Tag näher an die Haustüren der Bevölkerung. In den zwölf letzten Monaten verloren noch weit über 2,5 Millionen deutsche Soldaten, etwa so viele wie seit Kriegsbeginn zusammen, und rund 6oo.ooo Zivilisten ihr Leben, wurden acht Millionen Menschen durch den Luftkrieg obdachlos und das immer kleiner werdende 'Großdeutsche Reich' verwandelte sich zusehends in eine Trümmerlandschaft. Während es für die Kämpfe im Osten in dieser Endphase des Krieges viele Veröffentlichungen gibt, fehlt bisher für das Geschehen an der Westfront, das sich in vielem vom rasseideologischen Vernichtungskrieg im Osten unterschied, die große zusammenfassende Gesamtdarstellung. John Zimmermann hat sie jetzt geschrieben. Sein beeindruckender Überblick fußt auf einer immensen Quellenbasis. In klarer Diktion beschreibt er die politische und wirtschaftliche Lage 1944/45, den Zustand der Gesellschaft unter den Bedingungen des fünften und sechsten Kriegsjahres und die militärische Lageentwicklung ebenso wie die Rolle des NS-Propaganda- und Terrorapparates und den immer schlechter werdenden personellen und materiellen Zustand der deutschen Truppen. Ein Schwerpunkt des Buches ist die Frage, warum die Wehrmacht den Kampf, der längst aussichtslos geworden war, auch im Westen...

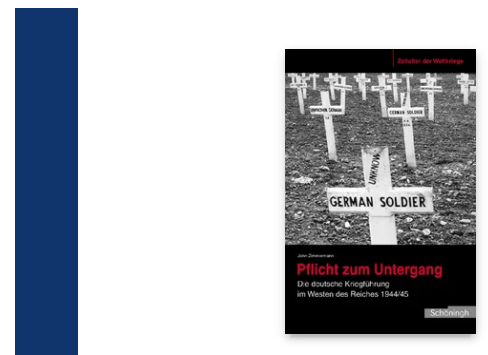

Pages: $5^{26}$

Seiten, $20 \mathrm{~s} / \mathrm{w}$ und 6 farb. Abb.

Language:

German

Subjects:

Modern History, History

Publisher: Brill |

Schöningh

Series:

Zeitalter der

Weltkriege,

Volume: 4

Hardback

Publication date: 22 Jul 2009

ISBN: 978-3506-76783-7

List price

USDD \$71.00 
For more information see brill.com

Order information: Order online at brill.com +44330 333 0049 | customerservices@brill.com Submission information: brill.com/authors

Titles published by Brill | Fink, Brill | mentis or Brill | Schöningh: +49(o)715413279216| brill@brocom.de 